\title{
Lisa Herzog* The Laws of Knowledge, Knowledge of Laws
}

\section{A “Political Epistemology” Perspective on Pistor's The Code of Capital}

https://doi.org/10.1515/ael-2020-0064

Published online September 7, 2020

\begin{abstract}
This commentary, part of the book symposium on Katharina Pistor's The Code of Capital, focuses in particular on the epistemic dimensions of the phenomena she describes. Knowledge can be coded as capital, through intellectual property rights, and these can be done in ways that unjustly favor privileged actors at the cost of the common good, as Pistor demonstrates with regard to the patenting of genetic markers. Interestingly, however, knowledge can also be appropriated without the use of legal tools, simply by appropriating data from consumers, as Zuboff, for example, has argued. A second epistemic dimension of Pistor's work lies in the fact that the legal coding of capital is itself little know and receives little public discussion. This, of course, plays into the hands of those who benefit by problematic forms of such coding. By putting these issues up for debate, The Code of Capital fulfill itself an important epistemic role, which can be categorized as a form of "democratic professionalism", i.e., professionals enabling a critical public discourse about the activities in their own field.
\end{abstract}

Keywords: capital, political epistemology, democratic professionalism

JEL Classification: D89

\section{Table of Contents}

1 The Laws of Knowledge, Knowledge of Laws

\section{Katharina Pistor's The Code of Capital: A Symposium}

1. The Code of Capital: How the Law Creates Wealth and Inequality - Core Themes, by Katharina Pistor, https://doi.org/10.1515/ael-2020-0102.

2. Three Projects in the New Law and Finance, by Dan Awrey, https://doi.org/10.1515/ael-20200069.

*Corresponding author: Lisa Herzo, University of Groningen, Groningen, Netherlands, E-mail: l.m.herzog@rug.nl 
3. The Laws of Knowledge, Knowledge of Laws: A “Political Epistemology" Perspective on Pistor's The Code of Capital, by Lisa Herzog, https://doi.org/10.1515/ael-2020-0064.

4. The Political Economy of Private Law: Comment on 'The code of capital - how the law creates wealth and inequality', by Matthias Thiemann, https://doi.org/10.1515/ael-2020-0077.

5. Capitalization and its Legal Friends, by Leon Wansleben, https://doi.org/10.1515/ael-2020-0063.

6. Theorizing Beyond "The Code of Capital”: A Reply, by Katharina Pistor, https://doi.org/10. 1515/ael-2020-0101.

\section{The Laws of Knowledge, Knowledge of Laws}

Katharina Pistor's masterly work The Code of Capital is one of those books whose message seems easy to capture, but which, when taken seriously, open up a revolutionary new way of looking at old questions. The problem of staggering material inequality, the fact of unequal access to the tools of law, the insight that neither "markets" nor "capital" are natural essences but rather man-made constructs: all this may sound familiar. And yet, by providing a detailed historical and systematic overview of the ways in capital is legally constructed, Pistor spearheads a paradigm shift. Instead of asking: "How could we redistribute from the rich to the poor?", the question becomes: "How could the legal framework of property rights be recalibrated such that certain inequalities do not even arise?"

A few years ago, Jacob Hacker has introduced the term "predistribution" for asking a parallel question about markets. ${ }^{1}$ The basic idea is to focus on "market reforms that encourage a more equal distribution of economic power and rewards even before government collects taxes or pays out benefits." ${ }^{2}$ When thinking about social justice, political philosophy - at least the Anglo-American mainstream - had long taken over models of markets from mainstream economics and seen them as institutions that we can either take or leave. In contrast, the perspective of "predistribution" sees markets as depending on institutions that are constructed by human beings, and that can be constructed differently. Therefore, markets themselves can also take on very different forms, and have very different consequences with regard to distributive justice.

Pistor goes one step further by making us see how even the most basic building blocks of markets are in turn constructed - or "coded", as she puts it - , and how this construction is biased towards the powerful classes in society. Thus, at the core of her book is a move that "de-essentializes" capital by looking at its legal construction.

1 Jakob Hacker, "The Institutional Foundations of Middle Class Democracy”, Progressive Governance, 2011, 33-37, available at https://www.jacobhacker.com/assets/hacker_pn.pdf (accessed April 16th, 2020).

2 Ibid., 35. 
Starting at the transition between the medieval and the early modern period, Pistor describes the "coding” of land, ideas, and other assets into "capital". The legal tools used for this purpose have been the same throughout the centuries, Pistor argues: property rights, contracts, rules about collateral, and legal vehicles such as trusts and corporations. She distinguishes four key features of the resulting assets: priority (whose claims come first?), durability (claims hold across time), universality (claims hold across space), and convertibility (the ability to transform claims into legal tender). ${ }^{3}$ Because these legal tools are mostly used by the privileged, they can be used to immunize the possessions of the rich against taxations, and secured over generations the legal coding of capital - currently mostly concerning intellectual property rights and financial derivatives - is thus an element in explaining rising inequality.

These historical analyses are a sobering read, but there is also an encouraging, and potentially emancipatory, message, contained in them: because capital relies on being coded, rather than being some kind of natural essence, it could also be coded differently. When reading about the various practices of "asset shielding", and the legal acrobatics used to secure private benefits, the political philosopher in me could not help but noticing that it does not matter what exactly one's theory of justice is - these practices will come out as wrong from pretty much any theoretical perspective that my discipline has so passionately argued about in recent decades! Whether you're a Rawlsian, a prioritarian, a utilitarian, thinking about justice in terms of "primary goods", welfare, resources, or opportunity for welfare: the practices Pistor describes seem hardly justifiable from any of these perspectives.

In what follows, I will focus on one particular dimension: the epistemic dimension, or dimension of knowledge and information, understood in a broad and non-technical sense. I will first focus in Pistor's account of the commodification of knowledge, which I connect to the appropriation of data that Shoshana Zuboff (2019) has recently highlighted. Then I move to the meta-level, arguing that given the high degree of differentiation in modern societies, such processes of appropriation are often not accessible to the broader public. I suggest that democratic professionalism can be an answer to this challenge and a strategy for re-politicizing such processes.

"Political epistemology" ${ }^{4}$ has become a vibrant field of philosophical research in recent years, exploring the various ways in which knowledge and politics are interrelated: the ways in which what we call "knowledge" can be influenced by

3 Katharina Pistor, The Code of Capital: How the law creates wealth and inequality. Princeton: Princeton University Press, 2019.

4 The first use of this term I found in the literature seems to be Althaus, Scott, Mark Bevir, Jeffrey Friedman, Hélène Landemore, Rogers Smith \& Susan Stokes. 2014. "Roundtable on Political Epistemology." Critical Review 26(1-2): 1-32. Before turning "political”, epistemology has already turned “social”, see e.g., Alvin I. Goldman, Knowledge in a Social World. Oxford: Oxford University Press, 1999. 
political circumstances, how "epistemic injustices" can distort deliberation, ${ }^{5}$ how democracies deal with knowledge, or how scientific research. can become politicized. ${ }^{6}$ In part inspired by science and technology studies (STS), but for the most part rejecting the relativist stance that STS scholars have sometimes implicitly or explicitly adopted, ${ }^{7}$ I venture the guess that this field could be an interesting interlocutor for "political economy", with benefits for both sides.

Pistor discusses the commodification of knowledge in Chapter 5, focusing on the struggles around the patenting of genetic code and the expansioan of intellectual property rights. ${ }^{8}$ Her chapter title, "Enclosing Nature's Code", anticipates her unease about the private appropriation of things which seem to belong to noone in particular, and argument that had, historically, also often been made about knowledge. ${ }^{9}$ Knowledge does not get less when it is shared; what gets less are the opportunities to make money from its use. From this arises the basic justification for intellectual property rights: they provide incentives to create certain forms of knowledge in the first place. ${ }^{10}$ But these rights need to be carefully calibrated to really serve the public good; they can easily turn into an instrument for one-sided enrichment. Pistor describes these latter dangers, focusing on the legal battles around human genes and diagnostic tools based on genetic analysis. ${ }^{11} \mathrm{~A}$ particularly insidious case are "data-generating patents": patents that might eventually be struck down by courts as illegal, but that allow companies to amass data that give them a head start over competitors. ${ }^{12}$ She also describes how corporations such as Google use trade secrecy to protect the data bases on which their business models are based. And trade secrecy, in contrast to patents or copyright, does not

5 On "epistemic injustice" see the pioneering work by Miranda Fricker, Epistemic Injustice: Power and the Ethics of Knowing (Oxford: Oxford University Press, 2007).

6 A good sense of authors and topics can be gained by looking at the Political Epistemology Network webpage: https://www.politicalepistemologynetwork.com (last accessed May 11th, 2020).

7 For an excellent volume that explores the interrelations between knowledge and politics from the perspective of STS, see Sheila Jasanoff (ed.), States of Knowledge: The Co-Production of Science and Social Order (London: Routledge, 2007).

8 Another topic that comes to mind here, and which is very well in line with Pistor's argument, are the (ab)uses of IP law when it comes to indigenous knowledge, which Rosemary Coombe, for examples, has explored in her work.

9 Pistor, The Code of Capital, 109.

10 See e.g., Richard A. Posner, "Intellectual Property: The Law and Economics Approach,” Journal of Economic Perspectives 19(2) (2005), 57-73. For a critical review of this debate see e.g., James Boyle, The Public Domain. Enclosing the Commons of the Mind (New Haven and London: Yale University Press, 2008), chap. I.

11 Pistor, The Code of Capital, 111ff.

12 Ibid., 126-7. 
have an expiry date, entrenching the position of certain companies in data-rich industries. ${ }^{13}$

On the issue of the private appropriation of "big data", Shoshana Zuboff's 2019 book The Age of Surveillance Capitalism has provided additional food for thought, and for concern. ${ }^{14}$ Zuboff draws on metaphors of unrightful appropriation of seemingly unoccupied land (see in particular her notion of "rendition", esp. in chap. 8) - exactly the kinds of cases the legal history of which Pistor traces. Interestingly, the appropriation of data often does not even seem to require the kind of legal codification as capital that Pistor describes: data are often not held as property, even though the control rights of companies are comparable. ${ }^{15}$ This is an indication that the legal activity of coding is not always necessary for the kind of accumulation processes that Pistor describes as happening by help of legal tools in other contexts. But neither would one be surprised to learn, say, that Facebook started a trust that would function as the legal owner of the business secret that protects its data treasures. Thus, the conceptual framework Pistor offers might still provide an interesting lens for understanding the appropriation of data. It would be fascinating to see a debate between Zuboff and Pistor, both avowed intellectual heirs of Polanyi, ${ }^{16}$ on the similarities and differences of their accounts, the role of legal code in the appropriation of data, and the possibilities of reform.

But the epistemic problems go further than that, because there is a meta-level: the knowledge about the ways in which knowledge, and other things, are legally coded, so often in unfair and biased ways, was for a long time also very unequally distributed. As Drahos puts it in his discussion of the international spread of intellectual property rights: "Just as regulatory scholars have neglected the practices of patent offices as an object of study, so NGOs have neglected them as objects of lobbying. The consumer movement, development NGOs and to a lesser extent trade unions have now heard the Trips wake-up call." ${ }^{17}$ But arguably, there is still

13 Ibid., 128-31.

14 Shoshana Zuboff, The Age of Surveillance Capitalism. The Fight for a Human Future at the New Frontier of Power. London: Profile Books, 2019.

15 On the scholarly debate of whether or not there should be legal property in data see e.g., StacyAnn Elvy, "Commodifying Consumer Data in the Era of the Internet of Things," Boston College Law Review 59 (2018), 423-545, at 463-6. As Elvy concludes: "Despite this scholarly debate, companies are currently commodifying consumer data as it has significant value for such entities." (p. 466). 16 Pistor refers to Polanyi e.g., on p. 11 and 19 of The Code of Capital; Zuboff refers to Polanyi e.g., on pos. 713-729 of Surveillance Capitalism.

17 Peter Drahos with John Braithwaite, Information Feudalism. Who Owns the Knowledge Economy? (New York: Earthscan, 2002), pos. 5320-22. 
very little debate, in the broader public, about the private appropriation of knowledge. These legal issues may seem too technical and mundane to explore them, and they do not easily cause public outrage. ${ }^{18}$ However, recently the awareness of the problem seems to be on the rise, at least with regard to digital content. ${ }^{19}$ But many current practices by corporations nonetheless look extremely problematic. ${ }^{20}$ Pistor's historical account of how many different assets have been coded into capital adds to the normative concerns about these practices, and to the urgency of raising public awareness about them.

Of course, this kind of ignorance plays into the hands of those who can then go about their business undisturbed. The situation is comparable to what Culpepper describes as "quiet politics" with regard to corporate control issues: corporations influence the rewriting of public rules, without much public attention and hence without debate or resistance, and thereby increase their power. ${ }^{21}$ Corporations might not even need to use tools such as non-disclosure agreements or the smokescreens of technical jargon, to remain outside the eye of the public.

This is a broader problem of modern, highly differentiated societies. Problems in one specific domain can be so difficult to access for outsiders that abuses or distortions, the casualty of which is society as a whole, can remain hidden for a long time. Sometimes it is only when a catastrophe happens that the public learns about the existence of these practices at all - and in retrospect, it often turns out that a handful of people anticipated the problems but tried in vain to raise awareness for them. ${ }^{22}$ If one imagines the democratic public as a bright, open space, then these specific domains can be pictured as niches that branch off from it, splitting into ever

18 As a frustrated activist who tried to raise awareness about institutional issues once remarked to me: "How do you get people interested in a topic if you don't have pictures of hungry children or cute animals?"

19 Here, there is on the one hand the open source movement, and on the other hand the privacy movement. But the political momentum to reign in the data collection by digital companies has been mixed at best. The European Union's General Directive on Data Protection is probably the most important step in the direction of privacy, but it is questionable whether it will be sufficient. 20 For a critical discussion of these topics see my "Privatizing Private Data”, in ed. Alon Harel and Avihai Dorfman, The Cambridge Handbook on Privatization (Cambridge, Cambridge University Press, forthcoming).

21 Pepper D. Culpepper, Quiet Politics and Business Power. Corporate Control in Europe and Japan. Cambridge: Cambridge University Press, 2012.

22 See e.g., the analysis of the Challenger Disaster by Diane Vaughan: The Challenger Launch Decision: Risky Technology, Culture and Deviance at NASA. Chicago: University of Chicago Press, 1996 - here, some engineers were very much aware of the risk of a launch at low temperatures (although Vaughan also discusses in great detail how shifting perceptions of risk over time "normalized" certain perceptions), but their voices were drowned out by other considerations. 
more fine-grained niches, like the root structure of some trees, or the kind of complex cave systems that one sometimes finds in limestone mountains. ${ }^{23}$

These structures raise obvious problems for democratic accountability: how can those within these small niches be held accountable? Only a handful of people may really understand what they are up to - and those may have conflicts of interests, because they are in the niche together with them. ${ }^{24}$ If you have such structures, creating public awareness can be extremely difficult; you need very stubborn, financially independent and technically competent journalists to even report about what is going on, and even then, public interest might be limited. But without the spotlight of the public, you cannot put these issues on the democratic agenda and re-politicize them, as Pistor, following Menke, pleads with regard to the legal matters she discusses. ${ }^{25}$

Much could be said about what it takes, for democratic societies, to address this challenge. Let me here focus on element of an answer, which Pistor gestures towards, by asking which incentives law school graduates face and how they could become more independent from capital, ${ }^{26}$ but which would deserve more attention, in my eyes. This is professional ethics, in the sense of a public-servicecommitment on the part of highly specialized experts who are difficult to hold accountable from the outside. In recent years, there have been some very interesting proposals for reviving a "democratic" or "civic" form of professionalism. ${ }^{27}$ Rejecting the old, hierarchical understanding of professionalism,

23 For a stimulating philosophical discussion of "hyperspecialization" see Elijah Millgram, The great endarkenment. Philosophy for an age of hyperspecialization (New York: Oxford University Press, 2015). He reads the story of the Tower of Babel as a metaphor for the way in which specialized knowledge makes the communication between individuals working in different fields more and more difficult. The problem of specialization within science was prominently described by John Hardwig, “The Role of Trust in Knowledge.” The Journal of Philosophy 88(12) (1991), 693708. Implications for the challenges of communication between experts and citizens from the perspective of deliberative democracy, are discussed by Thomas Christiano, "Rational deliberation among experts and citizens.” In: Parkinson, John / Mansbridge, Jane (eds.). Deliberative Systems. Deliberative Democracy at the Large Scale. Cambridge: Cambridge University Press, 2012, 27-51, and from the perspective of STS by Harry Collins and Robert Evans in Rethinking Expertise (Chicago and London: The University of Chicago Press, 2004) and Why Democracies Need Science (Cambridge: Polity Press, 2017).

24 See similarly Onora O’Neill, “Trust, Trustworthiness, and Accountability.” In: Capital Failure. Rebuilding Trust in Financial Services, eds. Nicholas Morris and David Vines. Oxford: Oxford University Press, 2014).

25 Pistor, The Code of Capital, pp. 217ff.

26 Ibid., p. 228-9.

27 See in particular Albert Dzur, Democratic professionalism. Citizen participation and the reconstruction of professional ethics, identity, and practice (University Park: The Pennsylvania State University Press, 2008) and Rebuilding Public Institutions Together: Professionals and Citizens in a 
but insisting on the need for differentiated expertise, these authors reflect on issues such as responsibility towards lay people, the porosity of the boundaries between professionals and the broader public, openness to questions and criticisms from the outside, and an ethical awareness of one's role as a professional in a democracy.

Such a form of "democratic professionalism" also seems needed for legal experts: at least some of them, and preferably some of the brightest and most sophisticated ones, need to serve not particular interest groups, but society as a whole. As pointed out earlier, the encouraging and emancipatory message of Pistor's book is that what is coded can be coded differently. But that requires that at least some of the "masters of the code", as Pistor calls them, ${ }^{28}$ need to attempt this rewriting: they need to write a code that is fair for everyone, and call out pieces of code that blatantly violates principles of justice. In fact, Pistor does not hide her sympathies for civil law countries, ${ }^{29}$ in which the creation of code by private law is more difficult. She points out cases, such as her opening example of the Maya in Belize who insisted on their property rights, in which lawyers have worked for the right side. But her whole argument seems based on the premise that there are more lawyers that code for the privileged, or that these are somehow more effective.

More steps are needed to redress this balance. Pistor argues for the need to rethink the financial dimension of US law schools such that fewer graduates have to work for capital in order to repay their student debt. ${ }^{30}$ Another strategy would be to recruit more law students from disadvantaged backgrounds, who would have the sensibilities to see the victims of injustices, and to make sure that they can also enter the areas of law where the coding of capital happens or is legally disputed. This could bring a more representative sample of individuals, hopefully with stronger public goods orientation, into the engine room of the law-and-capitalnexus.

Yet another step is one that Pistor does not discuss, but which her book actually exemplifies: the communication with the broader public, and the explanation of what seem to be highly obscure and technical legal issues in ways that lay people can understand. The dialog with the broader public is a key element of

Participatory Democracy (Ithaca: Cornell University Press, 2017), William M. Sullivan, Work and integrity. The crisis and promise of professionalism in America (San Francisco: Jossey-Bass, 2005), Alfred Moore, Critical elitism. Deliberation, democracy and the problem of expertise (Cambridge: Cambridge University Press, 2017). For a discussion see also Lisa Herzog, "Markt oder Profession? Die Politik zweier Wissenslogiken”, Leviathan 46(2) (2018), 165-187.

28 Pistor, The Code of Capital, chap. 7.

29 Ibid., esp. pp. 170-173.

30 Ibid., pp. 228-9. 
“democratic professionalism". Pistor understands how the coding works, and thus can provide the kind of "interactional expertise" that is needed to translate highly specialized knowledge from narrow niches into accounts and narratives that can be taken up by the broader public discourse. ${ }^{31}$ From that perspective, it is also to be welcomed that Pistor is not shy to make concrete proposals for what could be done, in a kind of to-do-list for democratic governments ${ }^{32}$ : reduce tax exemptions, be stricter about choice of law, reign in negative externalities of capital, end the legal enforceability of purely speculative contracts, and various other proposals.

Pistor is realistic about the hopes for reform, however. ${ }^{33}$ Towards the end of her book, she cites a joke about two Irish farmers who "met somewhere in the hills of Donegal and one asked the other for the best way to Dublin. "Don't start from here," was the answer" (p. 233). If what I have argued above is correct, the situation is even worse: in contrast to the second Irish farmer, we have hardly even begun, as societies, to understand that this is where we are. The general awareness of how knowledge and other assets are coded into capital needs to be raised, in order to create public and political debate about possible reforms. This requires bringing these topics into public discourse, writing about them in an accessible language, and clarifying the man-made nature of capital to policy-makers and a broader audience that all too often takes it to be unchangeable. The Code of Capital is a wonderful invitation to start that public debate, and it will hopefully make a difference in this respect. I warmly wish it many attentive readers!

31 The notion of "interactional expertise" is from Collins and Evans, Rethinking Expertise.

32 Ibid., pp. $223 \mathrm{ff}$.

33 One might add here, however, that the prospects for reform are probably not equally dire in all countries - but of course it does not help that the two countries that provide most of the legal tools for the current ways of coding capital come from, the UK and the US, do not provide high hopes. 